ENTREPRENEURSHIP AND SUSTAINABILITY ISSUES

ISSN 2345-0282 (online) http://jssidoi.org/jesi/

2021 Volume 8 Number 4 (June)

http://doi.org/10.9770/jesi.2021.8.4(34)
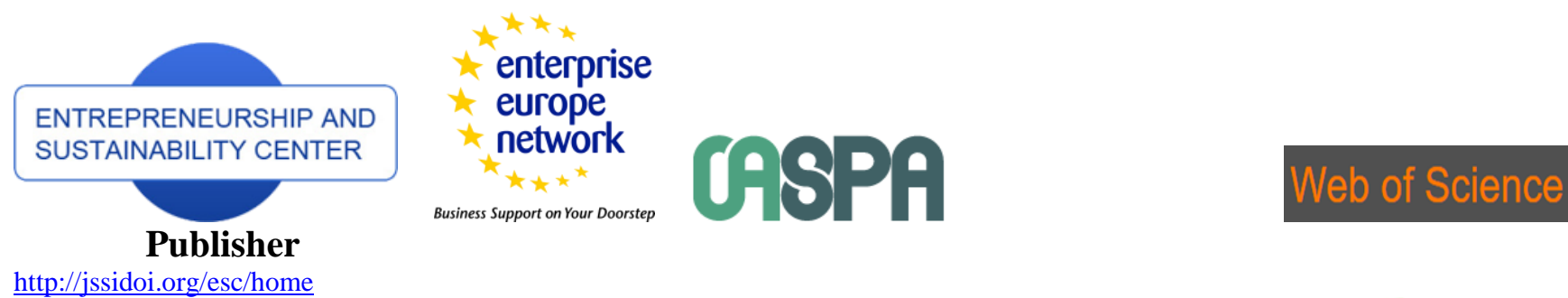

http://jssidoi.org/esc/home

Business Support on Your Doorstep PA

1 Clarivate

Analytics

\title{
UNDERSTANDING THE NATURE OF THE ECONOMIC GAME ULTIMATUM THROUGH THE PRISM OF PERSONALITY TRAITS*
}

\author{
Pavel Ziaran ${ }^{1}$, Radovan Bacik ${ }^{2}$, Beata Gavurova ${ }^{3}$, Richard Fedorko ${ }^{4}$ \\ 1,2,4 University of Prešov, Faculty of Management, Konštantínova 16, 08001 Prešov, Slovakia \\ ${ }^{3}$ Technical University of Košice, Faculty of Mining, Ecology, Process Control and Geotechnologies, \\ Letná 9, 04200 Košice, Slovakia
}

E-mails: ${ }^{1}$ pavel.ziaran@unipo.sk; ${ }^{2}$ radovan.bacik@unipo.sk; ${ }^{3}$ beata.gavurova@tuke.sk; ${ }^{4}$ richard.fedorko@unipo.sk

Received 18 February 2021; accepted 20 April 2021; published 30 June 2021

\begin{abstract}
Ultimatum game belongs to the classical economic experiments, frequently used to study altruism and pro-social behavior. The objective of the research is to understand relations between the personality and the ultimatum game from the responder's perspective. Participants ( $\mathrm{N}=224$, females $62 \%$ ) filled the web-based questionnaires on Hexaco-PI and hypothetic minimal acceptable sum as respondents in the ultimatum game. Data was analyzed by means of the structural equation model and the binominal regression model, using the narrow traits as input variables. Interestingly, the most frequented value of minimal acceptable amount was a fair offer $(50 \%$ of the total sum). A fair offer was expected by $50 \%$ of females and $42 \%$ of males; what erodes the traditional thesis of economic rationality, according to which any offer higher than 0 should be accepted. Hence, people have natural tendency to expect and require a fair deal. Results from the logit model show that the minimal acceptable sum in the ultimatum game is predicted, firstly, by liveliness and sociability (wider trait extraversion) and secondly, by sentimentality and dependence (wider trait emotionality). In other words, tendency to expect and require fair offer manifests at optimistic and joyful people able to create strong emotional connections. Logit model's results were reconfirmed by the structural equation models, where wider traits extraversion and emotionality were found statistically significant. Findings have interesting implications as regards the understanding of underlying psychological processes in the frame of altruistic decision-making.
\end{abstract}

Keywords: Ultimatum game; Hexaco-PI; personality; in-class experiment; altruistic behavior

Reference to this paper should be made as follows: Ziaran, P., Bacik, R., Gavurova, B., Fedorko, R. 2021. Understanding the nature of the economic game ultimatum through the prism of personality traits. Entrepreneurship and Sustainability Issues, 8(4), 571-583. http://doi.org/10.9770/jesi.2021.8.4(34)

JEL Classifications: D64, C92

Additional disciplines: economic experiments, altruistic behaviour, personality, in-class experime

\footnotetext{
* This article is one of the partial outputs under the scientific research grant 042PU-4/2020 - KEGA - Implementation of innovative approaches and teaching materials in the educational process of future managers. This article is one of the partial outputs under the scientific research grant VEGA 1/0694/20 - Relational marketing research - the perception of e-commerce aspects and its impact on purchasing behaviour and consumer preferences and VEGA 1/0609/19 - Research on the development of electronic and mobile commerce in the aspect of the impact of modern technologies and mobile communication platforms on consumer behaviour and consumer preferences.
} 


\section{ENTREPRENEURSHIP AND SUSTAINABILITY ISSUES}

ISSN 2345-0282 (online) http://jssidoi.org/jesi/

2019 Volume 6 Number 4 (June)

http://doi.org/10.9770/jesi.2019.6.4(34)

\section{Introduction}

Ultimatum game has been first proposed by Güth, Schmittberger \& Schwarze (1982). This game is a form of an economic experiment on money distribution between two players: allocator (or proposer) and responder (recipient) and belongs to the group of bargaining games (used earlier e.g. by Lloyd, 1970). In the first step, allocator decides on the distribution of money between the two persons. If respondent agrees with the proposal, both will receive the money in the proposed extent. However, if responder does not agree, both will receive nothing. The game ultimatum is closely related to the dictator game, which consists only from the first step of the process.

Since 1960's, economic games on money distribution (dictator, ultimatum, trust game, prisoners' dilemma) received lot of attention from the research community, bringing insights and understanding on the aspects as altruism, fairness or cooperation (Camerer \& Thaler, 1995). Analysis of economic experiments dictator and ultimatum by means of the Hexaco-PI was introduced by German professors Hilbig and Zettler and their collaborators. This is where inspiration for this research comes from. Relations between Hexaco-PI and the ultimatum game were analyzed in Hilbig \& Zettler (2009), in the form of an ex-ante decision of the proposer, and by Hilbig et al. (2013) in the form of ex-ante decision of the responder.

Hexaco - Personality Inventory came into existence on the basis of the lexical analysis, out of which a personality model consisting of six factors was created (Ashton et al., 2004, Lee and Ashton, 2008). The corresponding HEXACO model of personality represents an acronym for the six factors Honesty-Humility, Emotionality, Extraversion, Agreeableness, Conscientiousness, and Openness to Experience (Lee \& Ashton, 2006).

The objective of this research is to analyze psychological aspects underlying the decision-making of the responder, based on the personality traits as defined by Hexaco-PI (Lee \& Ashton, 2004), special focus is given on the gender differences. We believe that profound analysis of decision-making in the economic experiments might bring a valuable insight into understanding the human nature in the contemporary market-based society.

\section{Aspects of the ultimatum game (not measured psychometrically)}

The standard homo economicus model postulates that participants pursue their individual material interest and act rationally to achieve their goals. In such a case, the responder should accept any offer greater than zero from the proposer, and the proposer/allocator should make offers approaching zero (Rubinstein, 1982). However, these two predictions are rarely observed, and the empirical results differ dramatically from the predictions of the game theory, which assumes self-interest.

Camerer \& Thaler (1995) denote this deviation from a purely rational (economic) behavior as an anomaly. Subsequently, this game provides an interesting ground to study the phenomena as altruism, reciprocity, cooperation and inter-individual justice.

Theoretically, there are two possible strategies for the allocator, to propose a fair or an unfair offer, and consequently, responder can provide four possible outcomes (accept / refuse a fair / unfair offer).

From the point of view of a proposer there are two motivations to offer a higher sum: first the notion of fairness or second, in the context of limited information and in the context of a bounded rationality, proposers raise their offers because they expect that non-satisfactory offers might be rejected (Suleiman, 1996).

Binmore, Shaked, \& Sutton (1985) divide players in two groups, in the frame of the results of bargaining games, the people with the tendency to "play fair" and the people who behave selfishly and rationally like real economic agents. Similarly, Thaler (1988) points out that the fairness might play a significant role in determining the outcomes of negotiations and suggest two groups of players "fair men" and "games men". Fair men as proposer tend to choose 50-50 allocations, even when the risk of rejection is eliminated (e.g. in the dictator game).

Fehr \& Gächter (2002) suggest that the reason why the responder rejects the sum smaller than $50 \%$ is the altruistic teaching in the form of punishment where by means of rejection responder educates the proposer to behave in a more altruistic manner in the future. 


\section{ENTREPRENEURSHIP AND SUSTAINABILITY ISSUES}

ISSN 2345-0282 (online) http://jssidoi.org/jesi/

2019 Volume 6 Number 4 (June)

http://doi.org/10.9770/jesi.2019.6.4(34)

As an antidote for the researchers bounded by the economic rationality there are scientists looking for authentic roots of human behavior using children as research subjects. Benenson et al. (2007) that children aged four, six and nine naturally manifest altruistic behavior in the frame of dictator game (distributing stickers); though the older children or those with higher socioeconomic status turn to be more altruistic.

Fehr et al. (2008), finds the children at the age of 3 to 4 behave much more selfishly, when compared to the group of children at the age 7 to 8 . Furthermore, altruistic behavior manifests strongly among the children from the same social group (parochialism). Gummerum et al. (2010) confirmed similar results (dictator game, distributing stickers). Children aged 3 behave more selfishly than children at the age of 5 and girls were more altruistic than boys (for 5-years old girls the mode of distribution was $50 \%$ ).

Allgaier et al. (2020) carried out a classical ultimatum and dictator experiment with nine-years old children ( $\mathrm{N}=164)$, who were distributing candies (10 chewy candies, in total). In both cases, the fair split occurred in $75 \%$ of cases at ultimatum settings and $50 \%$ in the dictator setting. Some children made a hyper-fair offer (more than a half of candies): $5 \%$ of children under the dictator setting and $14 \%$ under the ultimatum. Authors found that honesty-humility (as defined by Hexaco-PI) predicts the distribution of all candies in both games; however, the distinction on the effects between the two games is not clear from the text.

\section{Hexaco personality tests and the research of prosocial behavior in dictator/ultimatum}

Hilbig \& Zettler (2009) analyzed ultimatum score from the proposer / allocator's perspective, by means of Hexaco-PI: correlation coefficient between the wider trait honesty-humility and the score in ultimatum was $r=$ 0.14; however this correlation was not statistically significant at the level $\mathrm{p}<0.05$ (two-sided). Similarly, as in our research the data were collected by means of the online questionnaire $(\mathrm{N}=134)$. Authors further found statistically significant correlations between Honesty-Humility and dictator game $(r=-0.27)$ and the social value orientations $(r=0.25)$. Social value orientation (SVO) denotes a proportion of the prosocial choices in the games proposing different combinations of money distribution between the allocator/proposer and the responder (Van Lange et al., 1997).

In the dictator game experiment $(\mathrm{N}=96)$, Hilbig et al. (2015) found following traits to be statistically significant: honesty-humility $(r=0.27 \mathrm{p}<0.01)$ and agreeableness $(r=0.19 \mathrm{p}<0.05)$. When using regression on all the 6 traits, besides honesty-humility, extraversion was the traits which contributed to the dictator game allocation.

In an ultimatum experiment, focused on the responder's decision, Hilbig et al. (2016) allowed the responder to punish the proposer by the reduction of proposer's payoffs. Amount of the payoff reductions was predicted by the agreeableness, as defined by Hexaco-PI, $(\mathrm{r}=-0.27 \mathrm{p}=<0.05 \mathrm{~N}=44)$, and not by the honesty-humility trait.

The research nearest to ours in its nature was carried out by Hilbig et al. (2013), who found positive relations between the ultimatum game and agreeableness $(\mathrm{r}=0.19 \mathrm{p}<0.01 \mathrm{~N}=212)$. With the same sample the score in the dictator game correlated with honesty-humility $(r=0.25 \mathrm{p}<0.01)$ and openness to the new experience $(\mathrm{r}=$ $0.15 \mathrm{p}<0.05)$.

\section{Approaches to measure the score in the ultimatum game}

Based on the literature review we can summarize, that the research on ultimatum game can be carried out in several forms. First, intention vs. actual decision. Secondly, focus on proposer or focus on responder. This combination creates four quadrants. Hilbig et al. (2009) use the approach where proposer decides on the actual allocation of money. In our research, we use the combination: focus on the responder and his/her intention to accept the minimal value, similarly as Hilbig et al. (2013, 2015). To our best knowledge, this approach is quite rare in the literature. Table 1 illustrates the research approaches. 


\section{ENTREPRENEURSHIP AND SUSTAINABILITY ISSUES}

ISSN 2345-0282 (online) http://jssidoi.org/jesi/

2019 Volume 6 Number 4 (June)

http://doi.org/10.9770/jesi.2019.6.4(34)

Table 1 Approaches to measure the score in the ultimatum game

\begin{tabular}{|c|c|c|}
\hline & Actual decision & Intention of the decision \\
\hline $\begin{array}{c}\text { Responder's } \\
\text { decision }\end{array}$ & $\begin{array}{c}\text { Ex-post approach. Responder was offered an } \\
\text { endowment and now decides (accepts / } \\
\text { rejects). }\end{array}$ & $\begin{array}{c}\text { Ex-ante approach. Responders decides on the } \\
\text { minimum limit to accept the offer (Hilbig et al. } \\
\text { 2013, Thielmann \& Hilbig, 2014). }\end{array}$ \\
\hline Proposer's decision & $\begin{array}{c}\text { Decides on the actual amount of the } \\
\text { endowment he or she allocates to responder } \\
\text { (Hilbig et al., 2009). }\end{array}$ & $\begin{array}{c}\text { Proposer estimates on the minimum limit the } \\
\text { responder might accept. }\end{array}$ \\
\hline
\end{tabular}

Economic games as dictator or ultimatum can be played in two forms: for real money e.g. Hilbig et al. (2015) or as hypothetical, where "participants are asked to imagine playing with another unknown person for money", e.g. Thielmann \& Hilbig (2014).

Objective of the research study is to reveal the psychological aspects behind the decision-making of responder (recipient) in the frame of the ultimatum game. And we formulate the research question as follows:

$R Q$ : What is the relation between the personality traits (as measured by the Hexaco-PI) and the decision in the frame of the ultimatum game from the responder's point of view (ex-ante), using the hypothetical form of question (i.e. value-based).

\section{Methodology}

\section{Research sample and procedure}

The players in the sample were undergraduate students of business and management $(\mathrm{N}=224$, females $62 \%)$. Sample consisted of the undergraduate students of the faculty of business and management in Czech Republic, aged between $21-22$. The group members have similar professional interests and belong to the same sociodemographic segment what is suitable, when analyzing personality traits and related aspects, as it reduces potential sources of variability.

Participants answered the web-based questionnaires on the HEXACO Personality Inventory (PI), and the two consecutive questions on the dictator and ultimatum game. Before the questions on dictator and ultimatum we included 2 questions on money distribution, according to the theory on social values (Van Lange et al., 1997), so that the participants adapt their thinking and "tune in" to the concept of money distribution, however we those questions were not included into the analysis.

\section{Instruments and measures}

We used a 60-questions form of the Hexaco-PI (Ashton \& Lee, 2009). Hexaco-PI has six wider personality traits: Honesty-Humility, Emotionality, Extraversion, Agreeableness, Conscientiousness, and Openness to Experience. Each wider trait consists of four more specific narrow traits. A detailed description of the traits can be found at hexaco.org (Hexaco homesite, 2020). In the analysis we opted for the narrow traits with the aim to encompass personality nuances explaining the underlying psychological processes.

In the ultimatum question we asked how the participants would distribute 1000 money units, between himself/herself and another (anonymous) person; knowing that if the other person shall not agree with the distribution, both receive 0 .

We use the hypothetical form of question regarding the money distribution, where the participants are asked "to imagine playing with another unknown person for money" (Thielmann \& Hilbig, 2014). Furthermore, we detached the material monetary value and its meaning by using the term "money units". Aim was to eliminate 
distraction caused by the real money associations (f.e. How much money I have now. What can I buy for it.), what to our opinion, helps to focus on the world of inner values of individuals.

\section{Data analysis}

As the first step, we carried out basic descriptive statistics and Mann-Whitney $U$ test to analyze gender differences in the raw score. Due to the nature of data distribution we divided data into two groups $(x>=500)$, with the intention to use the binomial logit regression. Subsequently we created two types of models: structural equation model and the binomial regression model.

We employed structural-equation modelling, using the SmartPLS software (Ringle, Wende \& Becker, 2015). We used latent variables correspondingly to the six HEXACO dimensions. Structural equation modelling, thanks to the computational methods, helps to solve problems as poor model fit, inflated factor correlations, and biased parameter estimates (Asparouhov \& Muthén, 2009).

We add the binomial logit regression model to reveal the relation between the ultimatum game and the narrow personality traits. For the sake of good empirical understanding, we add graphical analysis (using simple linear regression).

\section{Results}

\section{Analysis of the raw scores of the ultimatum game}

Table 2 shows the basis parameter of the ultimatum score, for males and females. Interestingly, the modus for both genders is 500; what is also evident from the histogram (fig. 1). Relative frequency of mode is $42 \%$ for males and $50 \%$ for females.

Table 2 Basis statistics, values in ultimatum game

\begin{tabular}{|c|c|c|c|c|c|c|c|}
\hline Sex & N valid & Mean & Std. dev. & Median & Mode & $\begin{array}{c}\text { Freq. of } \\
\text { modus }\end{array}$ & $\begin{array}{c}\text { Freq. of } \\
\text { modus \% }\end{array}$ \\
\hline Male & 85 & 387 & 199 & 499 & 500 & 35 & 42 \\
\hline Female & 139 & 421 & 142 & 500 & 500 & 70 & 50 \\
\hline
\end{tabular}

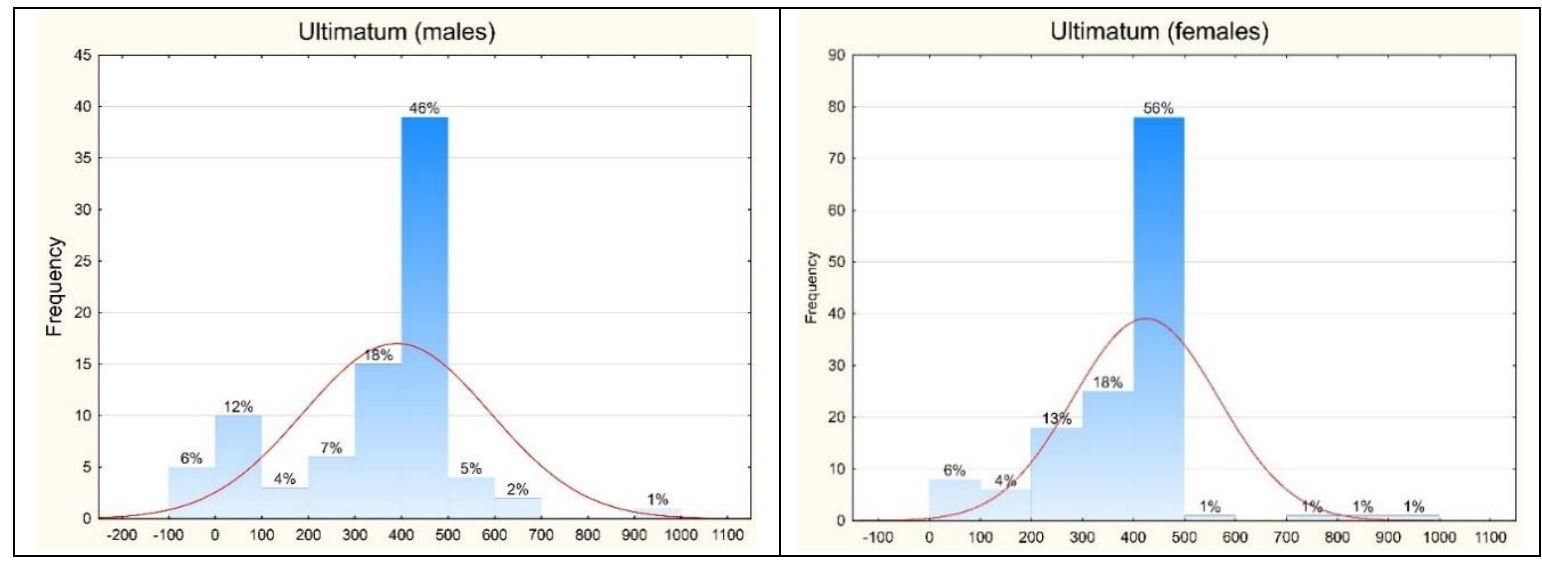

Figure 1 Histogram, values of scores in the ultimatum game, by genders Source: own elaboration

Mann-Whitney $U$ test, showed no statistically significant differences between genders as regards the ultimatum raw score $(\mathrm{Z}$ adj. $=-0.79 ; \mathrm{p}$-value $=0.43)$, even if the score's mean value for males is smaller than for females (mean value for males 387 / females 421). 


\section{Structural equation models}

This chapter brings the results of the structural equation model (SEM). Latent variables were constructed in line with the logic of the Hexaco model (Thielmann \& Hilbig, 2014). Input variables are narrow personality traits, grouped according to the wider traits, which represent the latent variables, output variable is the ultimatum score. Figure 2 shows the model

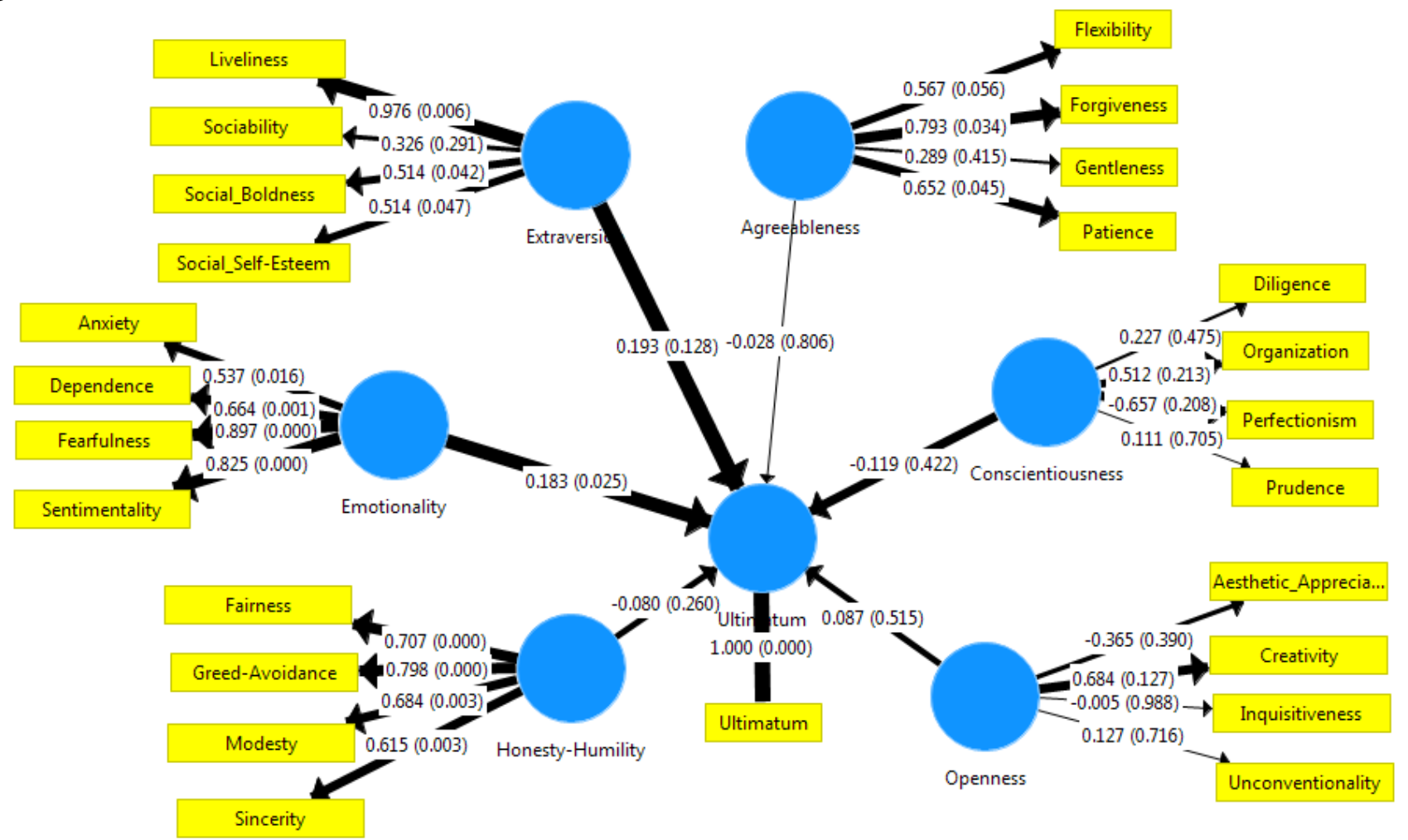

Figure 1 Structural equation model, Ultimatum vs. Hexaco personality traits. Numbers show path effects, p-values are in the brackets, width of lines illustrate absolute values of variables' weights. (Made by the software PLS-smart)

Source: own elaboration

Table 3 presents result of the SEM model calculation (bootstrapping method). Only the single trait emotionality is statistically significant $(\beta=0.183$; $p$-value $=0.025)$. Then the trait extraversion is relatively near the zone of acceptance $(\beta=0.192 \mathrm{p}$-value $=0.13)$. Other traits, honesty-humility, conscientiousness, openness and agreeableness are not statistically significant.

Table 3 Structural equation model, Ultimatum vs Hexaco personality traits, for both genders. Sorted by p-values

\begin{tabular}{|l|c|c|c|c|c|}
\hline & $\begin{array}{c}\text { Original } \\
\text { Sample }\end{array}$ & $\begin{array}{c}\text { Sample } \\
\text { Mean }\end{array}$ & $\begin{array}{c}\text { Standard } \\
\text { Deviation }\end{array}$ & T Statistics & P-values \\
\hline Emotionality -> Ultimatum & 0.18 & 0.19 & 0.08 & 2.24 & 0.03 \\
\hline Extraversion -> Ultimatum & 0.19 & 0.17 & 0.13 & 1.52 & 0.13 \\
\hline Honesty-Humility -> Ultimatum & -0.08 & -0.11 & 0.07 & 1.13 & 0.26 \\
\hline Conscientiousness -> Ultimatum & -0.12 & 0.00 & 0.15 & 0.80 & 0.42 \\
\hline Openness -> Ultimatum & 0.09 & 0.02 & 0.13 & 0.65 & 0.52 \\
\hline Agreeableness -> Ultimatum & -0.03 & -0.04 & 0.11 & 0.25 & 0.81 \\
\hline
\end{tabular}

Source: own elaboration 


\section{Analysis by means of ultimatum game through the prism of narrow traits, by logit model}

In order to understand better the results stemming from the structural equation model, we add the analysis by means of the logit model, using the narrow traits of Hexaco-PI. For the sake of the logit model construction, we split the participants into two groups, based on the ultimatum score ( $x<500$ and $x>=500)$, as shown in the table 4. Interestingly, we got the division of 51 to $49 \%$ for males, and 47 to $53 \%$ for females, what is suitable for the logistic regression.

Table 4 Frequency distribution, values in ultimatum divided into two categories, to be used in the binominal regression.

\begin{tabular}{|l|c|c|c|}
\cline { 2 - 4 } \multicolumn{1}{c|}{} & Sex & Freq. total & Freq. \% \\
\hline $\mathrm{x}<500$ & Male & 43 & 51 \\
\hline $\mathrm{x}>=500$ & Male & 42 & 49 \\
\hline Total & Male & 85 & 100 \\
\hline $\mathrm{x}<500$ & Female & 65 & 47 \\
\hline $\mathrm{x}>=500$ & Female & 74 & 53 \\
\hline Total & Female & 139 & 100 \\
\hline
\end{tabular}

As regards the quality, the model has following parameters: Cox-Snell R2 $=0.15$, Nagelkerke R2 $=0.20$; percentage of the correct predictions is $71.6 \%(\mathrm{x}>=500)$ and $64.8 \%(\mathrm{x}<500)$. Note: Aim of this research is not to develop a model which would exactly predict the responder's choice in the ultimatum game, but rather to provide an insight into the underlying psychological processes and corresponding personality traits. From this perspective, the quality of the logit model can be considered as satisfactory.

Table 5 presents the binominal regression model (all effects). In order to capture the subtle nuances of the psychological processes underlying the decision-making process, we add the analysis based on the narrow traits. Personality traits reaching the level of statistical significance ( $\mathrm{p}$-value $<0.05)$ are traits belonging under emotionality: dependence $(r=-0.40, p=0.04)$ and sentimentality $(r=0.47 \quad p=0.05)$; and the narrow traits belonging under extraversion: sociability $(r=-0.46 p=0.02)$ and liveliness $(r=0.56 p<0.01)$.

Table 5 Logit model, ultimatum game vs. narrow traits of Hexaco-PI (all effects)

\begin{tabular}{|c|c|c|c|c|c|c|}
\hline & & Estimates & Std. error & $\begin{array}{l}\text { Wald. } \\
\text { (Stat.) }\end{array}$ & $\begin{array}{c}\text { Odd } \\
\text { (ratio) }\end{array}$ & p-value \\
\hline & Abs. & 0.13 & 2.10 & 0.00 & & 0.95 \\
\hline \multirow{4}{*}{ Honesty-humility } & Sincerity & 0.30 & 0.21 & 2.04 & 1.35 & 0.15 \\
\hline & Fairness & -0.18 & 0.17 & 1.12 & 0.84 & 0.29 \\
\hline & Greed-Avoidance & 0.11 & 0.21 & 0.28 & 1.12 & 0.60 \\
\hline & Modesty & -0.13 & 0.18 & 0.58 & 0.88 & 0.45 \\
\hline \multirow{4}{*}{ Emotionality } & Fearfulness & 0.31 & 0.24 & 1.66 & 1.36 & 0.20 \\
\hline & Anxiety & -0.04 & 0.17 & 0.06 & 0.96 & 0.81 \\
\hline & Dependence $* *$ & -0.40 & 0.20 & 4.06 & 0.67 & 0.04 \\
\hline & Sentimentality $* *$ & 0.47 & 0.24 & 3.91 & 1.60 & 0.05 \\
\hline \multirow{4}{*}{ Extraversion } & Social Self-Esteem & 0.09 & 0.22 & 0.16 & 1.09 & 0.69 \\
\hline & Social Boldness & 0.20 & 0.19 & 1.01 & 1.22 & 0.31 \\
\hline & Sociability $* *$ & -0.46 & 0.19 & 5.50 & 0.63 & 0.02 \\
\hline & Liveliness $* *$ & 0.56 & 0.20 & 8.09 & 1.75 & 0.00 \\
\hline \multirow{4}{*}{ Agreeableness } & Forgiveness & -0.28 & 0.20 & 2.00 & 0.76 & 0.16 \\
\hline & Gentleness & -0.35 & 0.24 & 2.11 & 0.70 & 0.15 \\
\hline & Flexibility & 0.09 & 0.23 & 0.14 & 1.09 & 0.71 \\
\hline & Patience & 0.13 & 0.18 & 0.49 & 1.14 & 0.48 \\
\hline
\end{tabular}


ENTREPRENEURSHIP AND SUSTAINABILITY ISSUES

ISSN 2345-0282 (online) http://jssidoi.org/jesi/

2019 Volume 6 Number 4 (June)

http://doi.org/10.9770/jesi.2019.6.4(34)

\begin{tabular}{|c|c|c|c|c|c|c|}
\multirow{4}{*}{ Conscientiousness } & Organization & -0.34 & 0.19 & 3.33 & 0.71 & 0.07 \\
\cline { 2 - 7 } & Diligence & -0.23 & 0.23 & 1.04 & 0.79 & 0.31 \\
\cline { 2 - 7 } & Perfectionism & 0.22 & 0.22 & 0.92 & 1.24 & 0.34 \\
\cline { 2 - 7 } & Prudence & -0.06 & 0.21 & 0.09 & 0.94 & 0.77 \\
\hline \multirow{3}{*}{ Openness } & Aesthetic Appreciation & 0.02 & 0.17 & 0.02 & 1.02 & 0.89 \\
\cline { 2 - 7 } & Inquisitiveness & -0.01 & 0.16 & 0.00 & 0.99 & 0.95 \\
\cline { 2 - 7 } & Creativity & 0.19 & 0.18 & 1.14 & 1.21 & 0.29 \\
\cline { 2 - 7 } & Unconventionality & -0.20 & 0.26 & 0.60 & 0.82 & 0.44 \\
\hline
\end{tabular}

Source: own elaboration

Interestingly, at the level of wider traits, results from the binominal logit regression correspond to the results stemming from the structural equation modelling (table 3). Both models point out to the wider traits of extraversion and emotionality.

Figure 3 shows the graphical relation between the statistically significant personality traits and ultimatum game: liveliness, sociability (extraversion) and sentimentality, dependence (emotionality).

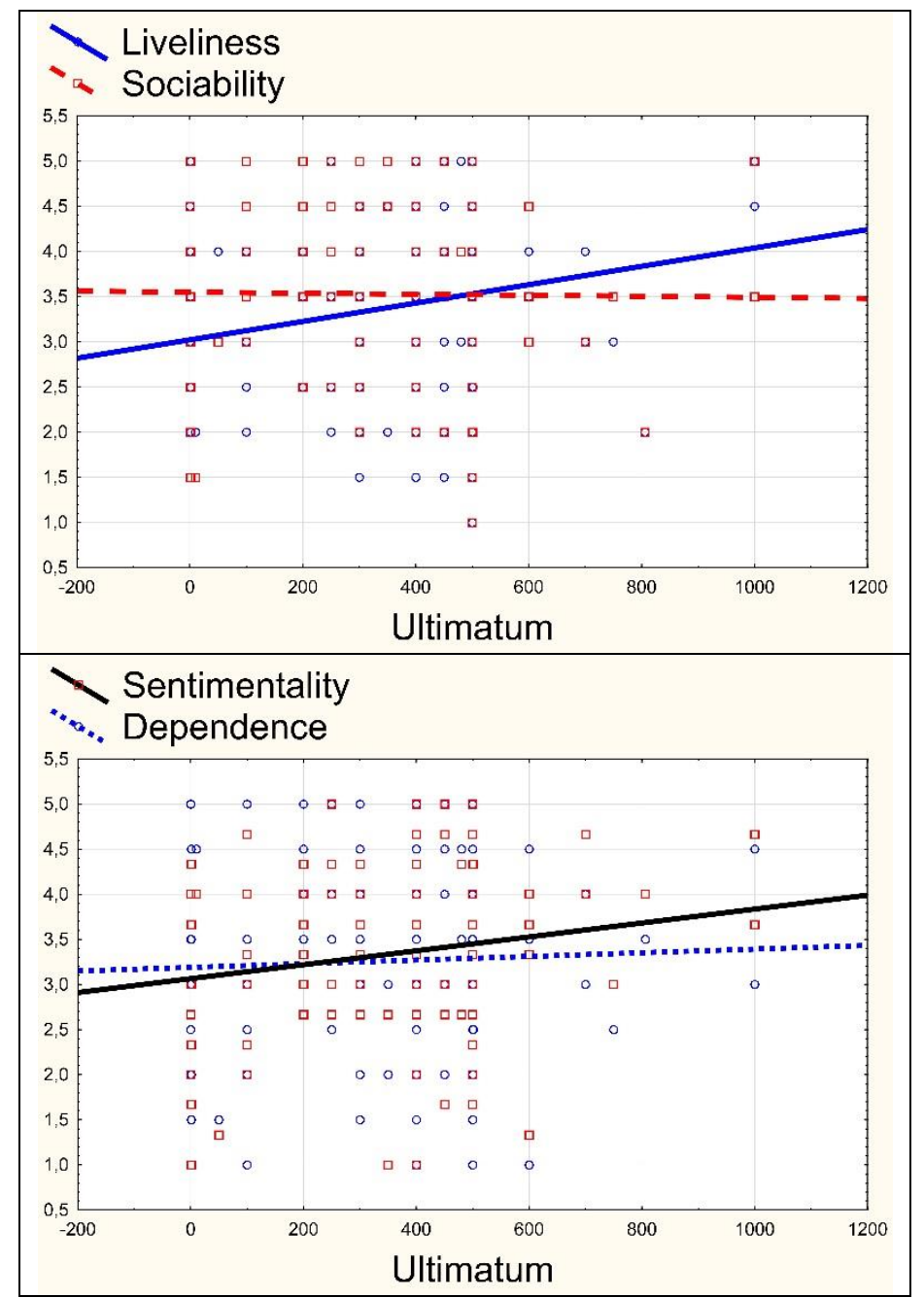

Figure 2 Relation between ultimatum game and liveliness and sociability (top) and sentimentality and dependence (bottom). Calculation by means of simple linear regression.

Source: own elaboration 


\section{ENTREPRENEURSHIP AND SUSTAINABILITY ISSUES}

ISSN 2345-0282 (online) http://jssidoi.org/jesi/

2019 Volume 6 Number 4 (June)

http://doi.org/10.9770/jesi.2019.6.4(34)

\section{Discussion}

\section{Analysis of the raw score of the ultimatum game}

Homo economicus vs natural tendency to fairness

Mode for both genders equals $50 \%$ of the total (table 1, figure 1), what in other words means that most of the participant expect a fair deal. This finding brings interesting implications.

Firstly, results contradict the thesis of the rational behavior as suggested by the game theory (Rubinstein, 1982), where the participant should accept any offer higher than zero. On the other hand, the fact that important part of participants would accept offers smaller than $50 \%$ might be interpreted as a tendency towards the rationality, as defined by the game theory.

Second implication regards fairness. As there is a substantial group of people who have tendency to expect fair offers (frequency of the mode is $50 \%$ for females and $42 \%$ for males), in line with Binmore et al. (1985) and Thaler (1988), we can hypothesize that the fairness (or the tendency to expect fairness) is a natural behavioral tendency).

As regards the gender differences, $50 \%$ for females and $42 \%$ for males expect fair value, on average females excepted 421 points and males 387. However, the results of the Mann-Whitney U test show no significant differences (table 2).

Responder's expectations (decision ex-ante) vs. reaction (decision ex-post)

From the research focused on the proposers (Camerer \& Thaler, 1995) we know that the most frequent proposition is between 30 and 40 and the most frequent rate of rejection is the value below 20 percent. Kahneman, Knetsch \& Thaler (1986) finds that mean of the minimal offer accepted by the responders is between 20 and 26 percent. While in our research the most frequent value of rejection is $50 \%$. We can only hypothesize, why is it so.

Perhaps, potentially, the most import reason for this difference, is the fact that we ask the responders on the value, that they would accept. In other words, we are basically asking about their expectations, where one can assume, that most responders would expect an ideal case, which is a fair deal of 50\%. However, from our everyday real life experience we know, that one thing is an expectation in the ideal situation, on the one hand; on the other hand, as a matter of fact, people under the force of the circumstances might accept the deals that are less convenient than ideal. What brings us back to the thesis rationality in terms of homo economicus.

\section{Relations between the ultimatum game and the personality traits}

Results based on the structural equation model (table 4) and the binomial model (table 7) bring the same results, at the level of wider traits, notably extraversion and emotionality.

Liveliness and sentimentality

As the logit model shows, there are two variables predicting significant and positive correlation with the ultimatum game score: liveliness $(r=0.56 \mathrm{p}<0.01)$ and sentimentality $(\mathrm{r}=0.47 \mathrm{p}=0.05)$, see table 4 and fig. 3 . Liveliness is defined as a tendency to manifest optimism, joy and energy; and sentimentality denotes to tendency to feel strong emotional bonds with others.

Hence, based on the results, as regards the role of the ex-ante responder in the ultimatum game, we can intuitively agree with the idea, that highly optimistic and joyful people who create strong emotional connections with other, will expect an anonymous counter-player to propose a higher offer (or a fair offer eventually). The narrow trait sociability and sentimentality belong under the roof of wider traits emotionality and extraversion, which predict the ultimatum scores according the structural equation model (fig. 2, table 2).

We believe that higher levels of ultimatum game score (from the responders' perspective) might be related with the notion of trustworthiness. According to Ashton, Lee \& De Vries (2014, p. 150) "the tendency to be trusting of others is associated with higher agreeableness and to some extent higher honesty-humility and higher extraversion (which relies to the tendency to feel confident and optimistic in general). Subsequently, these personal qualities are also reflected in the traits as sentimentality and liveliness. 


\section{ENTREPRENEURSHIP AND SUSTAINABILITY ISSUES}

ISSN 2345-0282 (online) http://jssidoi.org/jesi/

2019 Volume 6 Number 4 (June)

http://doi.org/10.9770/jesi.2019.6.4(34)

\section{Sociability and Dependence}

Binomial logit model (table 5, fig. 3) revealed another two variables predicting the ultimatum game score, both in negative way: dependence $(r=-0.40 \mathrm{p}=0.04)$ and sociability $(\mathrm{r}=-0.46 \mathrm{p}=0.02)$. Personality trait dependence assesses the need for emotional support from others, persons with low scores feel self-assured and solve their problem independently. Sociability is defined as a tendency to enjoy conversation, social interaction, and parties (Hexaco homesite, 2020).

As regards dependence, it is in line with empirical expectations that people who prefer to deal with their problems independently, without seeking help or emotional support will expect higher (or fair) offer in the ultimatum game. Subsequently, less emotionally self-assured people might be satisfied with lower (or less fair) offers.

As regards sociability, we do not see a straightforward theoretical or empirical explanation, why people with introverted tendencies (lower on the sociability scale) expect higher (or fairer) offers. We can only hypothesize. There are two types of hypothesis. First, there is a specific personality type with high tendency to except high score in ultimatum and this personality type ontologically integrate the trait of sociability.

The other type of hypothesis (which applies to the whole research) might work with the idea that similar people decide for different reasons, reasons other than the explicit personality traits; for example different personal values, life experiences or stages of the cognitive and moral development, etc. Consequently, there might not be clear and unambiguous patterns, in terms of the personality traits, at the level of the whole datasets, and inferential statistics thus might become inefficient.

Furthermore, as fig. 3 shows, slopes of the correlation lines (based on pair correlations) are not that steep, when compared to the slopes of the traits liveliness and sentimentality. Furthermore, in the frame of correlation analysis, both variables are statistically insignificant at level $\mathrm{p}<0.1$ (dependence $r=-0.03$ sociability $r=-0.06$ ).

Honesty-humility and Agreeableness

In our research, using the SEM and logit model, we did not find significant relations between the ultimatum game and agreeableness as did Hilbig et al. (2013) and Hilbig et al. (2016). On the other hand, the essence of liveliness and sentimentality, as defined by Hexaco-PI can be intuitively relied with some definitional aspect of agreeableness representing the capacity to forgive the wrongs, be lenient in judging others and willing to compromise and cooperate with others (Hexaco homesite, 2020).

We also found no relation between the ultimatum game and honesty-humility as did Hilbig \& Zettler (2009), using the proposer/allocators' perspective. We did not confirm statistically significant relation between the ultimatum game and the fairness (a component of the wider trait honesty-humility), knowing that the personality trait is a principal determinant of decision-making in the dictator game, which is principally similar.

However, table 5, presenting the logit model, indicates certain role of sincerity (a component of the honestyhumility trait), might play a certain role in the ultimatum decision-making process $(r=0.30 \mathrm{p}=0.15)$. Some other methods, especially correlational analysis or graphical methods show partial relations between ultimatum and honesty-humility and agreeableness, as the nature of the ultimatum game cannot be detached from the mental processes relied to these personality traits.

\section{Conclusion}

The objective of this research study was to reveal psychological aspects underlying the decision-making processes of the responder in the frame of the ultimatum game. We used personality questionnaire Hexaco-PI (Ashton \& Lee, 2009), which is both psychometrically valid, as well as empirically very well constructed.

Our research might be considered innovative from several perspectives. Firstly, there are only few research works employing similar methodology; notably combination of the personality questionnaire Hexaco-PI and the "ex-ante" decision-making from the responder's perspective (Hilbig et al. 2013, 2016).

Interestingly, we got results which are different from the two previous researches, however still empirically acceptable. Hilbig et al. $(2013,2015)$ found agreeableness to be the main and only predictor of the ultimatum game score. In our research it was liveliness and emotionality, which in its essence correspond to the context of trustworthiness (and strongly relates to the notion of agreeableness). We got principally similar results from two 


\section{ENTREPRENEURSHIP AND SUSTAINABILITY ISSUES}

ISSN 2345-0282 (online) http://jssidoi.org/jesi/

2019 Volume 6 Number 4 (June)

http://doi.org/10.9770/jesi.2019.6.4(34)

different models, employing different calculation methodologies: the structural equation model and the logit model, that both point at the positive influence of extraversion and emotionality on the height of the ultimatum game score.

Second innovative aspect stands from the fact, that we anchored our analysis at the level of narrow traits, unlike the previous researchers (Hilbig et al. 2013, 2015, 2016) who restrict their research to the level of wider traits. Apparently, approach based on the narrow traits provides more nuanced insights into the behavioral aspects. As we could see, some narrow traits affect the output in the mutually opposite direction, what the analysis at the level of wider traits cannot reveal. Thus, the analysis at the level of narrow trait might be more accurate.

Thirdly, we used hypothetical money (Thielmann \& Hilbig, 2014) and we detached the material monetary value and symbolic meaning by using the notion of "monetary units". Thus, participants do not get distorted by the real-life monetary implications as for example a shortage of money, or vise-versa. Instead, the notion of "monetary unites" evokes the authentic inner values of responders. And as our results confirm, the participants react to the question with a reasonable and meaningful variability, revealing the underlying differences related to the personality psychology.

We can conclude that our research offers a vivid and realistic insights into the psychological processes underlying the ultimatum game. Our findings bring both, theoretical understanding and empirical implications in the field of altruistic and pro-social decision-making of individuals.

\section{References}

Allgaier, K., Ścigała, K. A., Trautwein, U., Hilbig, B. E., \& Zettler, I. (2020). Honesty-humility and dictator and ultimatum game-giving in children. Journal of Research in Personality, 85, 103907. DOI: https://doi.org/10.1016/j.jrp.2019.103907

Ashton, M. C., \& Lee, K. (2001). A theoretical basis for the major dimensions of personality. European Journal of Personality, 15(5), 327353. DOI: https://doi.org/10.1002/per.417

Ashton, M. C., \& Lee, K. (2007). Empirical, theoretical, and practical advantages of the HEXACO model of personality structure. Personality and Social Psychology Review, 11(2), 150-166. DOI: https://doi.org/10.1177/1088868306294907

Ashton, M. C., \& Lee, K. (2009). The HEXACO-60: A short measure of the major dimensions of personality. Journal of Personality Assessment, 91(4), 340-345. DOI: https://doi.org/10.1080/00223890902935878

Ashton, M. C., Lee, K., \& De Vries, R. E. (2014). The HEXACO Honesty-Humility, Agreeableness, and Emotionality factors: A review of research and theory. Personality and Social Psychology Review, 18(2), 139-152. DOI: https://doi.org/10.1177/1088868314523838

Ashton, M. C., Lee, K., Perugini, M., Szarota, P., De Vries, R. E., Di Blas, L., ... \& De Raad, B. (2004). A six-factor structure of personality-descriptive adjectives: solutions from psycholexical studies in seven languages. Journal of Personality and Social Psychology, 86(2), 356. DOI: https://doi.org/10.1037/0022-3514.86.2.356

Asparouhov, T., \& Muthén, B. (2009). Exploratory structural equation modeling. Structural equation modeling: a multidisciplinary journal, 16(3), 397-438. DOI: https://doi.org/10.1080/10705510903008204

Benenson, J. F., Pascoe, J., \& Radmore, N. (2007). Children's altruistic behavior in the dictator game. Evolution and Human Behavior, 28(3), 168-175. DOI: https://doi.org/10.1016/j.evolhumbehav.2006.10.003

Binmore, K., Shaked, A., Sutton, J. (1985) Testing Noncooperative Bargaining Theory: A Preliminary Study. American Economic Review, 75, 1178-80. Retrieved April 5, 2020 from: http://www.dklevine.com

Camerer, C. F., \& Thaler, R. H. (1995). Anomalies: Ultimatums, dictators and manners. Journal of Economic Perspectives, 9(2), $209-219$. DOI: https://doi.org/10.1257/jep.9.2.209 


\section{ENTREPRENEURSHIP AND SUSTAINABILITY ISSUES}

ISSN 2345-0282 (online) http://jssidoi.org/jesi/

2019 Volume 6 Number 4 (June)

http://doi.org/10.9770/jesi.2019.6.4(34)

Fehr, E., Bernhard, H., \& Rockenbach, B. (2008). Egalitarianism in young children. Nature, 454(7208), 1079-1083. DOI: https://doi.org/10.1038/nature07155

Fehr, E., Gächter, S. (2002) Altruistic Punishment in Humans. Nature 415(6868), 137-40. DOI: https://doi.org/10.1038/415137a

Gummerum, M., Hanoch, Y., Keller, M., Parsons, K., \& Hummel, A. (2010). Preschoolers' allocations in the dictator game: The role of moral emotions. Journal of Economic Psychology, 31(1), 25-34. DOI: https://doi.org/10.1016/j.joep.2009.09.002

Güth, W., Schmittberger, R., \& Schwarze, B. (1982). An experimental analysis of ultimatum bargaining. Journal of Economic Behavior \& Organization, 3(4), 367-388. DOI: https://doi.org/10.1016/0167-2681(82)90011-7

Hexaco homesite (2020). Scale definitions (online). Retrieved April 5, 2020 from: http://hexaco.org/scaledescriptions

Hilbig, B. E., \& Zettler, I. (2009). Pillars of cooperation: Honesty-Humility, social value orientations, and economic behavior. Journal of Research in Personality, 43(3), 516-519. DOI: https://doi.org/10.1016/j.jrp.2009.01.003

Hilbig, B. E., Thielmann, I., Hepp, J., Klein, S. A., \& Zettler, I. (2015). From personality to altruistic behavior (and back): Evidence from a double-blind dictator game. Journal of Research in Personality, 55, 46-50. https://doi.org/10.1016/j.jrp.2014.12.004

Hilbig, B. E., Thielmann, I., Klein, S. A., \& Henninger, F. (2016). The two faces of cooperation: On the unique role of HEXACO Agreeableness for forgiveness versus retaliation. Journal of Research in Personality, 64, 69-78. DOI: https://doi.org/10.1016/j.jrp.2016.08.004

Hilbig, B. E., Zettler, I., Leist, F., \& Heydasch, T. (2013). It takes two: Honesty-Humility and Agreeableness differentially predict active versus reactive cooperation. Personality and Individual Differences, 54(5), 598-603. DOI: https://doi.org/10.1016/j.paid.2012.11.008

Kahneman, D., Knetsch, J. L., \& Thaler, R. (1986). Fairness as a constraint on profit seeking: Entitlements in the market. The American Economic Review, 728-741. Retrieved March 15, 2020 from: https://econpapers.repec.org/

Lee, K., \& Ashton, M. C. (2006). Further assessment of the HEXACO Personality Inventory: Two new facet scales and an observer report form. Psychological Assessment, 18(2), 182. DOI: https://doi.org/10.1037/1040-3590.18.2.182

Lee, K., \& Ashton, M. C. (2008). The HEXACO personality factors in the indigenous personality lexicons of English and 11 other languages. Journal of Personality, 76(5), 1001-1054. DOI: https://doi.org/10.1111/j.1467-6494.2008.00512.x

Lloyd, J. W. (1970). Role Playing, Collective Bargaining, and the Measurement of Attitude Change. Journal of Economic Education, 1 (2), 104-110. Retrieved March 12, 2020 from: https://search.proquest.com/

Ringle, C. M., Wende, S., \& Becker, J. M. (2015). SmartPLS 3. Boenningstedt: SmartPLS GmbH. Retrieved March 12, 2020 from: https://www.smartpls.com

Rubinstein, A. (1982). Perfect Equilibrium in a Bargaining Model. Econometrica, 50 (1), 97-109. DOI: https://doi.org/10.2307/1912531

Suleiman, R. (1996). Expectations and fairness in a modified ultimatum game. Journal of Economic Psychology, 17(5), 531-554. DOI: https://doi.org/10.1016/S0167-4870(96)00029-3

Thaler, R.H. (1988). Anomalies: The Ultimatum Game. The Journal of Economic Perspectives, 2 (4), 195-206. DOI: https://doi.org/10.1257/jep.9.2.209

Thielmann, I., \& Hilbig, B. E. (2014). Trust in me, trust in you: A social projection account of the link between personality, cooperativeness, and trustworthiness expectations. Journal of Research in Personality, 50, 61-65. DOI: https://doi.org/10.1016/j.jrp.2014.03.006

Van Lange, P. A., De Bruin, E., Otten, W., \& Joireman, J. A. (1997). Development of prosocial, individualistic, and competitive orientations: theory and preliminary evidence. Journal of Personality and Social Psychology, 73(4), 733. DOI: https://doi.org/10.1037/0022-3514.73.4.733 


\section{ENTREPRENEURSHIP AND SUSTAINABILITY ISSUES}

ISSN 2345-0282 (online) http://jssidoi.org/jesi/

2019 Volume 6 Number 4 (June)

http://doi.org/10.9770/jesi.2019.6.4(34)

\section{Acknowledgements}

This article is one of the partial outputs under the scientific research grant 042PU-4/2020 - KEGA - Implementation of innovative approaches and teaching materials in the educational process of future managers.

This article is one of the partial outputs under the scientific research grant VEGA 1/0694/20 - Relational marketing research - the perception of e-commerce aspects and its impact on purchasing behaviour and consumer preferences and VEGA 1/0609/19 - Research on the development of electronic and mobile commerce in the aspect of the impact of modern technologies and mobile communication platforms on consumer behaviour and consumer preferences.

Pavel ZIARAN works as a researcher at the Faculty of Management, University of Prešov, Slovak Republic. His research interests concern psychology in organizations, psychology of motivations and application of neurosciences in the field of marketing and management.

ORCID ID: https://orcid.org/0000-0001-8282-9012

Radovan BACIK has been working as a lecturer at the Department of Marketing and International Trade of the University of Prešov since 2009. In his research activities he is focusing on the issues of Public relations, Public relations in tourism, marketing of selected areas, strategic marketing, presentation of management and marketing, communication in management, branding and innovation and online marketing.

ORCID ID: $\underline{\text { https://orcid.org/0000-0002-5780-3838 }}$

Beata GAVUROVA (corresponding author) is an expert in finance, financial analysis and financial risk management. She focuses in her research work on issues of measurement and performance management in various sectors, process management and process optimization, strategic and performance benchmarking. Her dominant research area is the development and testing in the management and performance measurement, the evaluation of methodologies and the preparation of an application platform for innovative management and performance measurement with the support of ICT. She led several national projects, has participated in many international projects targeting the innovative applications of ICT in the private and public sector.

ORCID ID: https://orcid.org/0000-0002-0606-879X

Richard FEDORKO has been working as a lecturer at the Department of Marketing and International Trade of the University of Prešov since 2014. In his research activities he is focusing on the issues of online marketing and e-commerce, especially on the fields of online advertising, online reputation, social media, customer support, consumer behaviour and mobile marketing.

ORCID ID: https://orcid.org/0000-0003-3520-1921

Make your research more visible, join the Twitter account of ENTREPRENEURSHIP AND SUSTAINABILITY ISSUES: @Entrepr69728810

Copyright (C) 2021 by author(s) and VsI Entrepreneurship and Sustainability Center

This work is licensed under the Creative Commons Attribution International License (CC BY).

http://creativecommons.org/licenses/by/4.0/

(c) (i) Open Access 